\title{
Folklor informasiya təhlükəsizliyində və informasiya təhlükəsizliyi folklorda
}

\author{
Hikmət Quliyev \\ AMEA Folklor İnstitutu, Bak1, Azərbaycan \\ quliyevh@mail.ru
}

\begin{abstract}
Xülasə- Məqalədə informasiya təhlükəsizliyi kontekstində folklorun rolu, eyni zamanda folklorun özünün informasiya təhlükəsizliyi məsələləri araşdırılmışdır. İnternetin sürətlə genişlənməsi, insanların gündəlik həyat rejimində yeri və rolunun artması, ən müxtəlif ehtiyac və istəklər baxımından şəxslərin ondan asılıığın güclənməsi, bütövlükdə, informasiya təhlükəsizliyinin aktuallaşmasına - kibercinayətkarlığın, kiberzorakılığın, gizli sosial şəbəkə və proseslərin aşkarlanmasına gətirib çıxarmışdır. Müəyyənləşdirilmişdir ki, bu kontekstdə folklor unikal imkanlara malikdir. Qeyd olunmuşdur ki, informasiya təhlükəsizliyinin predmeti kimi, milli folklor resurslarının etibarlı saxlanması, bütövlüyünün və tamlığının qorunması, həmin resursların əlyetərliliyinin təmin olunması müasir dövrün aktual çağırışlarındandır.Eyni zamanda rəqəmsal folklor resurslarının on müxtəlif parametrlər üzrə təsnif olunması və İnternet mühitində onların intellektual analizinin həyata keçirilməsi ilə bağlı perspektivlər şərh edilmişdir.
\end{abstract}

Açar sözlor - informasiya tohlükosizliyi, folklor, roqəmsal folklor, folklorun qorunması, internet folkloru, kompüter folklorşünaslığı, kibercinayotkarlıq, milli identiklik.

\section{GİRİs}

Müasir dövr informasiya-kommunikasiya texnologiyalarının sürətlə yayılması və elektron texnologiyalar hesabına yeni imkanların meydana çıxması ilə xarakterizə olunur. Rəqəmsal texnologiyaların, elektron mühitin, qlobal informasiya şəbəkəsinin mövcudluğu elmin bütün sahələrində olduğu kimi, folklorşünaslıqda da yeni istiqamət və təmayüllərin meydana çıxarılmasını zəruri edir. $\mathrm{Bu}$ baxımdan milli təhlükəsizliyin əsas komponentlərindən olan milli-mənəvi dəyərlərin qorunması, xalq mədəniyyətinin, folklorun müasir dünyanın tələblərinə müvafiq şəkildə informasiya təhlükəsizliyi kontekstində araşdırılması kifayət qədər aktual məsələdir. Bir tərəfdən informasiya təhlükəsizliyi kontekstində folklorun spesifik imkanlarının öyrənilməsi, digər tərəfdən isə folklorun özünün informasiya təhlükəsizliyi ilə bağlı problemlərinin araşdırılması, rəqəmsal folklor resurslarının vahid sistem daxilində birləşdirilməsi, elektron mühit daxilində hər bir folklor resursunu xarakterizə edən parametrlərin müəyyənləşdirilməsi, onların beynəlxalq standartlara uyğunlaşdırılması, rəqəmsal folklor resurlarının təsnif olunmas1, İnternet mühitindo milli folklor resurslarının müxtəlif parametrlər üzrə intellektual analizi üçün imkanların yaradılması, aktual dövriyyədə olan folklor vahidlərinin tezliyinin müəyyənləşdirilməsi, eləcə də, illərlə toplanmış folklor resurslarının etibarlı qorunmasının, tamlığının və əlyetərliliyinin təmin olunması kimi məsələlər bu qəbildəndir.

Beləliklə, məsələyə üç əsas aspektdən baxmaq mümkündür:

Birincisi, informasiya təhlükəsizliyi kontekstində folklorun unikal imkanlarından istifadə etməklə müəyyən situasiya və hallarda məxfiliyin, qeyri-müəyyənliyin, gizli virtual sosial şəbəkə və qrupların aşkarlanması, onlara münasibətdə adekvat üsul və metodların müəyyənləşdirilməsi;

Íkincisi, kompüter texnologiyalarının imkanları hesabına milli folklor resurslarının rəqəmsallaşdırılması, elektron mühitə daxil edilməsi, həmin mühit daxilində etibarlı qorunması,

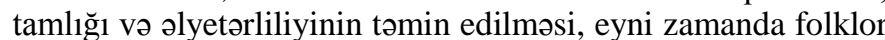
resurslarının intellektual analizinin təmin edilməsi üçün hər bir folklor resursunu identifikasiya edəcək parametrlərin müəyyənləşdirilərək qeyd olunması;

Üçüncüsü, İnternetdə - virtual kommunikativ mühitdə, sosial şəbəkə, forum və saytlarda gedən folklor proseslərinin, folklorlaşma və yaxud defolklorlaşma tendensiyalarının, müvəqqəti folklor ənənələrinin, yeni nəsil folklor faktlarının, folklorik forma və qəliblərin, nəhayət, İnternet folklorunun multidissiplinar metod və yanaşmalar, informasiyakommunikasiya texnologiyalarının tətbiqi əsasında analiz olunmas1.

\section{II. İNFORMASIYA TӘHLÜKӘSIZLLIYİ ANLAYIȘI}

İnformasiya təhlükəsizliyi geniş anlayışdır və son zamanlar aktuallaşmasına baxmayaraq, tarixən müxtəlif daşıyıcılar - daş, dəri, kağız və s. üzərində olan informasiyanın qorunması, məxfiliyinin təmin edilməsi kimi məsələlər kontekstində mövcud olmuşdur. Hesab etmək olar ki, kommunikasiya yarandığı andan etibarən informasiyanın aktuallığı və vacibliyi dərk olunmuş, insanlar arasında informasiyanın qorunması, etibarlı şəkildə saxlanılması və ötürülməsinə böyük əhəmiyyət verilmişdir. Xüsusilə də, qrup şəklində təşkilatlanmada, sosial təsisat kimi formalaşmada, ən nəhayət dövlət olaraq təmərküzləşmədə informasiya təhlükəsizliyinin önəmi daha da artmış, belə demək mümkündürsə, mövcudluq şərtinə çevrilmişdir.

Elmi ədəbiyyatlarda informasiya təhlükəsizliyi anlayışına müxtəlif cür yanaşma mövcuddur: "İnformasiya təhlükəsizliyinin predmeti çox zaman informasiyanın 


\section{“Informasiya tohlükosizliyinin aktual multidissiplinar elmi-praktiki problemlori” IV respublika konfransı, 14 dekabr 2018-ci il}

konfidensiallığının, tamlığının və əlyetərliliyinin təmin edilməsi kimi başa düşülür. Lakin informasiya təhlükəsizliyinin predmeti daha genişdir. İnformasiya təhlükəsizliyi təkcə kompüter təhlükəsizliyindən və şəbəkə təhlükəsizliyindən ibarət deyil. Müasir cəmiyyətdə informasiya təhlükəsizliyi cəmiyyətin bütün sosial proseslərinə (kursiv bizimdir - H.Q.) nüfuz edir, istənilən dövlətin milli təhlükəsizliyinin ayrılmaz tərkib hissəsinə çevrilir" [7]

Müasir dövrdə informasiyanın çox sürətli şəkildə yayılması, informasiya üzərində istənilən əməliyyatın aparılması imkanın olması və s. informasiyanı çox zəruri və strateji bir məfhuma çevirmişdir. İnformasiya üzərində manipulyasiyalar etməklə cəmiyyətə təsir etmək, dezinformasiya yaymaqla stabilliyi pozmaq, sosio-psixoloji xaos yaratmaq mümkündür. Eyni zamanda hər hansısa yararlı, bəşəriyyətin inkişafına dəstək verə biləcək informasiyadan səmərəli istifadə etməklə, onu geniş kütlələr arasında yaymaqla böyük xeyir əldə etmək olar. $\mathrm{Bu}$ onu göstərir ki, informasiyanın bəd üzü ilə bərabər, xoş üzü də vardır. Odur ki, “ ... informasiyalaşdırma bəşəriyyətin inkişafını sürətləndirməklə yanaşı, milli, regional və qlobal təhlükəsizliyə yeni təhdidlər də yaradır" [7].

Lakin dünyada gedən bu proseslərdən - informasiya müharibələri və toqquşmalarından kənarda qalmaq mümkün deyildir. $\mathrm{Bu}$ isə təbii olaraq, informasiya təhlükəsizliyini aktuallaşdırmış olur. İnformasiya təhlükəsizliyinin texnogen xarakterli problemləri ilə yanaşı, informasiyanın məzmunundan irəli gələn infogen mənşəli problemləri də vardır.

Bir zamanlar insanlar informasiyanın qitlı̆̆ından, azlığından əziyyət çəkirdilərsə, hal-hazırda bu proses tamamilə əksinə cərəyan edir. Bu gün bəşəriyyət informasiyanın ifrat bolluğunun, informasiya selinin içərisində "itib-batmaq" təhlükəsi ilə üz-üzədir. $\mathrm{Bu}$ da dünyanı informasiya təhlükəsizliyi paradiqması qarşısında qoymuşdur. Belə bir reallıq kontekstindo folklorun yerinin və rolunun qiymətləndirilməsi, onun imkanlarının ortaya çıxarılması olduqca aktuallıq kəsb edən məsələdir

\section{FOLKLOR İNFORMASIYA TӘHLÜKӘSİZLIYI KONTEKSTINDO}

Məlumdur ki, hazırda İnternet informasiya mübadiləsi və kommunikasiyanın əsas vasitəsinə çevrilmişdir. İnsanlar ən müxtəlif ehtiyac və zərurətlə əlaqədar olaraq günün daha çox hissəsini İnternetdə keçirirlər. $\mathrm{Bu}$ isə İnternet ətrafında müəyyən bir sosiumu formalaşmışdır. Burada gedən proseslərə müvafiq olaraq, dünyanın müxtəlif ölkələrinin qanunvericiliyində dəyişikliklər edilmiş, kibercinayətkarlığa qarş1 mübarizənin hüquqi tənzimlənməsi ilə bağlı müvafiq qərarlar qəbul olunmuşdur. Lakin bütün bunlara baxmayaraq, bu gün İnternet vasitəsilə - sosial şəbəkələr, söhbət otaqları (chat rooms), sayt və bloqlarla insanların aldadılması, insan alveri, psixoloji təsiretmə ("Mavi Balina" hadisəsi - qorxutma, hədələmə, tabe etdirmə kontekstində), cəmiyyəti yalan və şayiələr vasitəsilə yönləndirmə faktları kifayət qədər geniş yayılmışdır.
Təsadüfi deyildir ki, "Mətn analizi və kibercinayətkarlıq”la bağlı geniş tədqiqatlar aparan Berry M.W. və Kogan J. Internetin bu məsələdə rolunu aşağıdakı kimi şərh edir: "İnternet böyüməyə və daha gənc nəsillərə təmas etməyə davam edir. Sinif yoldaşları, dostlar və ümumi maraqları olan insanlarla əlaqə qurmaq imkanları getdikcə artır. Elektron poçt, onlayn çat və sosial şəbəkələr eyni şəhərdəki insanlarla bərabər, dünyanın o biri başındakı şəxslərlə də ünsiyyət saxlamağımıza şərait yaradır. Təəssüflər olsun ki, yeni texnologiyadan neqativ işlər üçün istifadə etmə fürsəti onun özü ilə bərabər gəlir. İnternetdən və söhbət otaqlarından xeyli əvvəllər də cinsi zorakılar və yırtıcılar var idi. Kiberzorakılıq və internet yırtıcılığı kompüter istifadə etmədə kifayət qədər təcrübəyə sahib olmayan, xüsusilə də yeniyetmə və gənclər üçün təhlükə yaradır. İnternet əlaqəsi cib telefonlarına qoşulduqca, portativ oyun cihazları və çox oyunçulu oyun konsolu gənclərin təması və istifadəsi üçün daha böyük yollar açd1" [3]

İnternet mühitinin hüququn formalaşdırılması, buradakı proseslərin hüquqi tənzimlənməsi, cinayətkarlığın qarşısının alınması və s. kimi məsələlər İnternet mühitində fərdi məsuliyyətin gücləndirilməsini zəruri edir. Lakin İnternetə daxil olmaq və ondan istifadə etmək azad xarakterlidir. İnsanlar Internetə daxil olarkən hər hansı bir biometrik məlumatlarla üz cizgisi, əl izi və s. ilə deyil, İP ünvanlarla qeyd olunurlar. IP ünvanların müəyyən bir qurğu barədə məlumat verməsinə baxmayaraq, həmin qurğunun arxasında kimin əyləşdiyini müəyyənləşdirmək, geniş mənada desək, istifadəçilərin identifikasiya olunması çox çətin məsələdir. Yaxud bu gün real sosial-mədəni proseslərin virtual mühitə transformasiyası, eləcə də virtual mühitin, sosial şəbəkə, bloq və saytların sosialmədəni proseslərin cərəyan etdiyi əsas məkana çevrilməsi kontekstində, gizli sosial qrupların yaranması, onlar arasında müəyyən metaforik-simvolik işarələrlə şifrələnmiş kommunikasiya imkanların mövcud olması müşahidə olunur ki, belə proseslərin də aşkarlanması olduqca mürəkkəbdir. Deməli, İnternetdə dövriyyədə olan məlumatların çox hissəsi anonim xarakteri daşıyır. Başqa sözlə desək, anonimlik İnternetin fəlsəfəsindən (müqayisə üçün qeyd edək ki, anonimlik və yaxud kollektivlik folklor proseslərinin cərəyan etməsi üçün "hava və su" qədər vacib məsələdir) irəli gəlir. Tədqiqatçılar qeyd edir ki, "İnternetin anonim təbiəti kiberzorakılığgn yayılmasına kömək edə bilər" [3]

Bununla əlaqədar olaraq, İnternet istifadəçilərinin identifikasiyası üçün səsin, şəklin, dəsti-xəttin, üslubun (leksikonun) analiz olunması çox aktual məsələdir. Məsələn, hər hansı bir şəxsin profili onun üslubu, leksikonu, şifahi və ya yazılı nitq aktında buraxdığı səhvləri, cümlənin strukturu, təkrarları ilə müəyyən olunur. Bunun üçün mətnlərin kompüter analizi deyilən fənn vardır ki, e-dövlətin təhlükəsizliyi kontekstində bir sira metodlardan istifadə olunur [2]. Berry M.W. və Kogan J. yazırlar ki, "müxtəlif qaynaqlardan kiberzorakılıq və kiberyırtıcılıqla bağlı transkriptləri araşdırarkən, kiberhücumçular və kiberyırtıcılar tərəfindən kimliyin maskalaması və aldatmada istifadə olunan oxşar taktikalarla qarşılaşırıq" [3]. Müəlliflərin qeyd etdiyi oxşarlığı təkcə taktikalarda deyil, eyni zamanda, kollektiv reaksiya və 
münasibətə əsaslanan folklorik deyim, davranış və ifadələrdə müşahidə etmək mümkündür.

Bir sözlə, identifikasiya üçün bir sira üsullar mövcuddur. Lakin bəzən həmin üsulların özü də yetərli olmur. Təhlükəli və ya şübhəli obyekt haqqında nə şəkil, nə səs, nə də hansısa bir biometrik məlumat əldə oluna bilmir. Yalnız həmin obyektin göndərdiyi mətnlər, müəyyən nitq bütövləri və ya cümlələr əlçatan olur ki, məhz bunlar əsasında analiz aparmaq zərurəti yaranır. Belə bir məqamda folklor informasiya təhlükəsizliyində “ümid yeri” kimi ortaya çıxır.

İnformasiya təhlükəsizliyi kontekstində folklorun rolu onun daşıdığı mahiyyət və spesifika ilə bağlıdır. Hesab edirik ki, informasiya təhlükəsizliyinin təmin edilməsində folklorun verdiyi unikal imkanları aşağıdakı aspektlərdən dəyərləndirmək olar:

\section{Folklor sosial qrupun spesifik kimliyi kimi}

- $\quad$ Fərd aid olduğu sosial qrupun folklorik portretini işarələyir;

- $\quad$ Fərd aid olduğu sosial qrupun peşə, dünyagörüş, kollektiv maraq spesifikasını təcəssüm etdirir;

Fərd aid olduğu folklor qrupunun ənənəviləşmiş, sabitləşmiş, digər üzvlər tərəfindən "tanınan” davranış və leksikon özəlliyinə sahibdir;

\section{Folklor etnik identifikator kimi}

Folklor onu yaradan və ya danışanın milli kimlik (etnik və qrup kimliyi), milli xarakter və tipologiyasının müəyyənləşməsində açar rolunu oynaya bilər;

- Folklor milli obraz, süjet və motivlərin spesifik cizgilərini əks etdirən güzgüdür;

Folklor danışıldığı dili, üslubu və dialekt spesifikasının təcəssüm etdirən kommunikativ aktdır;

\section{Folklor kriptoqrafik informasiya kimi}

- Folklor gerçəkliyi və ya situasiyaları metaforiksimvolik işarələrlə əks etdirən spesifik işarələr sisteminə malikdir;

Folklor faktı arxasında müəyyən bir informasiya və ya mesaj olan "indeksdir" [9]

Folklor nitq aktı içərisində başqaları tərəfindən anlaşılmayan yerli deyim, frazem və sözlərdə ehtiva olunmaq imkanına malikdir;

$\mathrm{Bu}$ mənada folklor informasiya təhlükəsizliyində unikal imkanlara malik kodlaşmış, kriptoqrafik informasiya mənbəyidir. Həmin informasiya əsasında götürülən obyekt barədə ilkin koordinatları müəyyənləşdirmək mümkündür. Çünki hər bir fərd, o cümlədən İnternet istifadəçisi kommunikativ prosesdə və yaxud hər hansı bir davranış aktında aid olduğu folklor mühitini, folklor qrupunu, nəhayət folklor kimliyini istər-istəməz büruzə etdirir. $\mathrm{Bu}$ isə folklor vasitəsilə informasiya təhlükəsizliyi kontekstində müəyyən bir kontentin, yazılı və ya şifahi nitqin müəllifinin, gizli sosial qrup və proseslərin folklor profilini yaratmağa imkan verir. Kompüter texnologiyaları və müəyyən analitik metodlarla həmin folklor profilini ən müxtəlif parametrlər üzrə xarakterizə etmək mümkündür. Təbii ki, burada "məqalələr, veb səhifələr, müzakirə forumları, bloqlar kimi mətnlərin geniş blokundan əsas terminləri, xüsusiyyətləri, hadisələri çıxarmaq və atributlar arasında münasibətlərin müəyyən olunmasında istifadə olun"an text mining metodlarından yararlanmaqla "avtomatik olaraq müxtəlif yazılı mənbələrdən informasiyanı" çıxarmaq "yeni, əvvəllər məlum olmayan informasiyanın kompüter tərəfindən aşkar" etmək mümkündür. [2]

Berry M.W. və Kogan J. kiberzorakılıq və kibercinayətkarlıqla mübarizədə text mining texnologiyalarının mühüm rol oynaya biləcəyini vurğulayaraq qeyd edir ki, "text mining-in alt sahəsi kimi sosial baxımdan əlaqəli və çox maraqlı olan bu istiqamət elmi ictimaiyyətin diqqətini cəlb etmək üçün yalvarır”. Tədqiqatçılar həmçinin bu məsələdə multidissiplinar yanaşmanı da irəli sürürlər: "kibercinayətin anlaşılması, təsbit edilməsi ve qarşısının alınması məsələsində şəbəkə mühəndislərinin, psixoloq alimlərin, sosioloqların, hüquq-mühafizə orqanlarının və kommunikasiya mütəxəssislərinin qarşılıqlı əlaqəsi” çox vacibdir. [3].

Hesab edirik ki, ümumilikdə informasiya təhülkəsizliyinin müxtəlif parametrləri üzrə (kibercinayətkarlıq, kiberzorakılıq, aldatma və s.) analizlərin aparılmasında folklordan istifadənin imkanları da təhlil olunmalı, bu istiqamətdə yeni metod və üsullar araşdırılmalıdır. Çünki psixoloji gerçəklik - təbiiemosional mahiyyətdən qaynaqlanan, sosial mühit və şəraitlə, lokal məkan və coğrafiya ilə, linqvistik tipologiya - yerli dil və dialektlə, milli xarakter və stereotiplərlə bağlı olan folklor milli identikliyin müəyyənləşdirilməsi baxımından informasiya təhlükəsizliyinin komponenti kimi araşdırma üçün geniş imkanlar açır.

\section{FOLKLORUN İNFORMASIYA TOHLÜKӘSIZLIYI}

Məlumdur ki, folklor milli identikliyin predmeti kimi strateji əhəmiyyət kəsb edir. İnformasiya təhlükəsizliyində folklorun rolu olduğu kimi, müasir dövrdə rəqəmsallaşan dünyada folklor informasiyasının da özünəməxsus təhlükəsizlik problemləri vardır. $\mathrm{Bu}$ sahədəki mövcud tədqiqatları, əldə olunmuş qənaət və nəticələri ümumiləşdirsək, problemin üç əsas istiqamətini vurğulamaq olar:

1.Milli folklor resurslarının müasir dünyanın informasiya tələblərinə, rəqəmsal standartlarına uyğunlaşdırılması və elektron mühitdə yerləşdirilməsi məsələləri;

2.Milli rəqəmsal folklor resurslarının informasiya təhlükəsizliyinin təmin edilməsi məsələləri:

- Folklor resurslarının etibarlı saxlanması;

- Folklor resurslarının tamlığının qorunması;

- Folklor resurslarına əlyetərliliyin təmin olunmasi;

3.Milli rəqəmsal folklor resurslarının İnternet analizinin aparılması məsələləri: 


\section{“Informasiya tohlükosizliyinin aktual multidissiplinar elmi-praktiki problemlori” IV respublika konfransı, 14 dekabr 2018-ci il}

- real mühitdən toplanılmıș rəqəmsal folklor resurslarının İnternet analizi;

- $\quad$ virtual mühitdə gedən folklor proseslərinin intellektual analizi.

Kompyuter folklorşünaslığı üzrə sanballı tədqiqatlar müəllifi olan Timothy R.Tangherlini bu sahədə 4 istiqamətə xüsusi diqqət yetirilməsini qeyd edir:

1) toplama və arxivləşdirmə,

2) indeksləşdirmə və klassifikasiya,

3) vizuallaşdırma və naviqasiya,

4) analiz [12]

Bəllidir ki, uzun illər ərzində folklor nümunələrinin toplanılması, tərtibi və nəşri istiqamətində xeyli işlər görülmüş, milli arxivlər və kolleksiyalar hazırlanmışdır. Lakin həmin folklor nümunələrinin elektronlaşdırılması, rəqəmsal texnologiyalar əsasında sistemli şəkildə standartlaşdırılması və İnternet mühitində yerləşdirilməsi müasir dövrün informasiya reallıqlarından doğan zərurətdir. Qloballaşan dünyada milli identikliyin qorunması məhz İnternet mühitinə sistemli şəkildə inteqrasiya olunmaqdan keçir. $\mathrm{Bu}$ isə öz növbəsində elektron informasiya mühitinin spesifik problemləri ilə - informasiya təhlükəsizliyinin təmin olunması ilə müşayiət olunur. "Edövlətin informasiya təhlükəsizliyini sosiumun elə vəziyyəti kimi müəyyən etmək olar ki, bu zaman şəxsiyyət, cəmiyyət və dövlət təbii və süni meydana çıxan, informasiya və kommunikasiya axınları şəklində çıxış edən, ictimai və fərdi şüurun qəsdən deformasiya olunmasına, şəxsiyyətin, cəmiyyətin və dövlətin varlığı üçün vacib əhəmiyyəti olan infrastrukturun məhv edilməsinə yönəlmiş təhdidlərdən fasiləsiz olaraq etibarlı və hərtərəfli qorunsun" [6;10] Edövlətin mühüm komponentlərindən biri kimi, milli-mənəvi dəyər kəsb edən qeyri-maddi mədəni irsin, folklorun da elektron mühitdə kənar təhdidlərdən etibarlı və hər tərəfli şəkildə qorunması çox vacib və strateji məsələdir.

Bir sıra dünya ölkələrinin təcrübəsinə nəzər saldıqda aydın olur ki, informasiya texnologiyalarının tətbiqi əsasında folklor arxivlərinin rəqəmsallaşdırılması, onların müxtəlif parametrlər üzrə təsnif olunması, həmin folklor resursları üzərində analizlərin aparılması istiqamətində mühüm işlər görülmüşdür [1].

Lakin "Big Data" erası kimi xarakterizo olunan hazırki mərhələni T.R.Tangherlini zəngin folklor resursları (tarixi, rəqəmsal doğulan (rəqəmsallaşdırılan deyil, birbaş olaraq, rəqəmsal mühitdə yaranan mənasında - H.Q.) yaxud hibrid formalı) ilə komputer tədqiqatlarının aparıldığ1 ilkin dövr" [11, 10] kimi qiymətləndirir. Alim yazır ki, bir çox folklor kolleksiyalar mühəndislər tərəfindən tətbiq olunan ümumi standartlara "Big Data"-dan daha çox "orta və kiçik" verilənlərə uyğun gəlsələr də, bu yanaşmaların folklor üçün müvafiqliyi gözardı edilməməlidir. [11, 10]

\section{FOLKLOR RESURSLARININ KOMPÜTER ANALIZI}

Kompyuter texnologiyalarının tətbiqi hesabına bir neçə istiqamətdə folklorun intellektual analizini aparmaq mümkündür. İlkin olaraq, illər boyu toplanılmış və arxviləşdirilmiş folklor nümunələrinin rəqəmsal formata gətirildikdən sonra analiz perspektivləri barədə danışmaq olar.

Dünyada folklor resurslarının vahid sistem daxilində folklor bankı çərçivəsində rəqəmsallaşdırılması, hər bir folklor vahidinin standart parametrlərlə təsnif olunması təcrübəsi mövcuddur. Təqdiqatlardan aydın olur ki, folkor resurslarının verilənlər bazası - müxtəlif arxivlərdə, kolleksiya və kataloqlarda əsasən iki istiqamətdə aparılmışdır. Bunlardan birincisi folklorun janrlar üzrə, digəri isə toplayıcı (və ya toplayıcı şəbəkəsi) üzrə sistemləşdirilməsidir [5].

Lakin bir məsələnin üzərində xüsusi dayanmaq lazımdır ki, folklor resurslarının çoxparametrli intellektual analizi folklor bankına daxil edilmiş nümunələrinin pasportlaşdırılması ilə birbaşa bağlıdır. Çünki folklor nümunəsi sahədən toplanılarkən onunla bağlı kontekstual məlumatların da qeyd olunması çox vacib məsələdir. Məsələn hər hansı bir folklor vahidinin təsnif edilməsi ilə bağlı aşağıdakı informasiyaların qeyd olunması lazımdır:

Söyləyici ilə bağlı məlumatlar - yaş, peşə, cins, məkan (doğulduğu yer, yaşayış yeri,), miqrasiya barədə məlumat, etnik mənşə və $\mathrm{s}$.

Mətnlə bağlı məlumatlar - janr, növ, aktuallaşma situasiyas1, müxtəlif parametrlər üzrə beynəlxalq kataloqlarda nömrələnmə və $\mathrm{s}$.

Auditoriya ilə bağlı məlumatlar - mətnin söylənildiyi sosial qrup, peşə tərkibi, yaş həddi və s.

Təbii ki, bu meyarların sayını kifayət qədər artırmaq mümkündür və sistemin çoxölçülülüyü məhz bu meyarların sayı ilə düz mütənasibdir. Folklor resursları nə qədər çox meyarlar əsasında təsnif olunarsa, bir folklor vahidinin nə qədər çox əlaməti qeyd olunarsa, onun üzərində intellektual analiz imkanları da bir o qədər artmış olar.

Çünki "rəqəmsal databazaların ən mühüm avantajlarından biri də məhz onların çoxölçülü analizlər üçün gərəkli olmasıdır. E.Ilyefalvi qeyd edir ki, folklorşünaslar üçün verilənlər bazasının ən liberal yeniliyi ondan ibarətdir ki, burada mətnlər bir kateqoriya və ya tip üzrə əlaqələnməmişdir. Mətnlər eyni zamanda bir sira kateqoriyalar üzrə əlaqələndirilmişdirlər ki, bu da nəhayətdə onlar arasında mövcud ola biləcək çoxölçülü münasibətləri aşkarlamağa imkan verir [5].

\section{FOLKLOR RESURSLARININ ÇOXPARAMETRLI ANALIZİ İMKANLARI}

Folklor resurslarının elektronlaşdırılaraq müxtəlif parametrlər əsasında vahid şəbəkədə yerləşdirilməsi, əslində, rəqəmsal texnologiyalarının tətbiqi ilə folklorşünaslıqda yeni imkanların yaradılmasıdır. Burada "əsas məqsəd mətn materialı üzərində çoxparametrli mətn işləmələrini həyata keçirmək və daha sonra həmin mətnləri/verilənləri çox modullu bir şəbəkəyə təqdim etməklə daha geniş araşdırma suallarına cavab verməkdir" [4]

Macar tədqiqatçısı E.İlyefalvi XX əsrin əvvəllərində dövrün texnoloji imkanları çərçivəsində ortaya çıxan tip kataloqunun folklorşünaslıq tədqiqatları üçün kataliz rolunu oynadığını 


\section{“Informasiya tohlükosizliyinin aktual multidissiplinar elmi-praktiki problemlori” IV respublika konfransı, 14 dekabr 2018-ci il}

qeyd edərək yazır: "Databaza özü-özlüyündə bütün suallara cavab verə bilməz. Yeni texnologiya, prosedur ve nəzəriyyə ən azı həll edə bildiyi qədər cavabsız suallara cavab verəcəkdir. Bununla bərabər, bütün bunlar gələcək paradiqmanın problemi olacaqdır. Hazırki çoxölçülü, rəqəmsal mətn hazırlığı, yeni şərh və analizlərə yol açacaq, bu da bizi, (sehr, cadu kimi) folklor mətnlərinin mürəkkəb və qarışıq fenomenlərini anlamağa yaxınlaşdıracaqdır" [4]

Göründüyü kimi, folklorşünaslıqda bir zamanlar mətnlərin motiv və ya süjetlər üzrə kataloqlaşdırılması, kolleksiya və arxivləşdirmə prinsiplərinin inkişaf etdirilməsi yeni tədqiqatlar üçün geniş imkanlar yaratmışdır. Müəyyən bir motivin dünyanın müxtəlif bölgələrinin folklor faktları üzrə izlənilmə imkanlarının yaradılması mədəni analogiyaların, iqtibas və əlaqələrin, universal psixoloji qanunauyğunluqların aşkarlanmasına gətirib çıxardı ki, bu da müasir dünya folklorşünaslığının intellektual inkişaf tarixində mühüm rol oynadı. Təbii ki, İKT-nin tətbiqi, rəqəmsal texnologiyaların yeni imkanlarından istifadə folklorşünaslığın tamamilə fərqli bir mərhələyə qədəm qoymasına gətirib çıxaracaqdır. Milli folklor resurslarının ən müxtəlif parametrlər üzrə vahid sistem daxilində rəqəmsal formatda cəmləşdirilməsi və onlar üzərində intellektual metodlarla analizlərin aparılması, heç şübhəsiz ki, yeni nəticələrin əldə olunmasına mühüm töhfə olacaqdır. Təbii ki, perspektivdə milli folklor resurslarının açıq informasiya sistemi daxilində digər xalqlara məxsus folklor resursları ilə əlaqəli şəkildə analiz imkanları daha fərqli tutuşdurma, müqayisə və qənaətlərə səbəb olacaqdır. $\mathrm{Bu}$ isə özlüyündə folklor informasiyasının təhlükəsiz şəkildə qorunması ilə bərabər, informasiya təhlükəsizliyi kontekstində folklorun imkanlarını daha da genişləndirəcəkdir. Belə ki, informasiya təhlükəsizliyinin predmeti ola biləcək hər hans1 bir obyekt (mətn, şəkil, audio, video resurs, fərd və ya gizli sosial qrup) çoxsaylı folklor banklarının Data bazaları əsasında analiz olunma imkanı qazanacaqdır. $\mathrm{Bu}$ isə, informasiya təhlükəsizliyi kontekstində folklorun ən unikal və spesifik imkanlara malik təhlükəsizlik komponenti kimi araşdırılmasını bir daha zəruri edir.

\section{FOLKLOR RESURSLARININ INTERNET ANALİŻ}

Folklorun informasiya təhlükəsizliyi kontekstində mühüm problemlərindən biri də rəqəmsal folklor resurslarının İnternet analizinin aparılması məsələləridir. Yuxarıda da qeyd etdiyimiz kimi, burada iki əsas istiqamət mövcuddur. Bunlardan birincisi, real mühitdən toplanılmış rəqəmsal folklor resurslarının İnternet analizi, digəri isə virtual mühitdə gedən folklor proseslərinin intellektual analizidir.

Müxtəlif parametrlər üzrə vahid sistem daxilində cəmlənmiş folklor resurslarının onlayn mühitdə İnternet analizinin aparılması üçün çox geniş imkanlar mövcuddur:

Hər bir rəqəmsal folklor resursuna sayğac yerləşdirməklə həmin resurslara olan müraciətləri hesablamaq mümkündür.

- Müəyyən bir zaman kəsiyində həmin folklor resurslarına olan müraciətlərin sayına əsasən reytinq müəyyənləşdirmək, hansı janrların daha aktiv, hansıların isə passiv olduğunu dəqiqləşdirmək mümkündür.

- Folklor resurslarına olan müraciətlərin hansı ərazidən, ölkə daxilindən və xaricdən olmasını aşkarlamaq, məsələn, dünya azərbaycanlıların bu resurslarla əlaqəsini izləmək maraqlı nəticələrin ortaya çıxmasına şərait yarada bilər.

- $\quad$ Hər hansı bir folklor resursuna müraciətlərin sayının artma və azalma tendensiyaları müəyyənləşdirilə bilər.

Virtual mühitdə gedən folklor proseslərinin intellektual analizi, əslində, İnternet folklorunun araşdırılması ilə bağlı məsələdir. Bəllidir ki, bu gün arxivlərdə toplanılmış folklor resursları elektron mühitə daxil edilməklə bərabər, sosial şəbəkə, bloq və saytlar hesabına İnternet folkloru da meydana gəlməkdədir. Belə folklor nümunələri real və ya virtual sosial proseslərdən qaynaqlanmasından asılı olmayaraq, onların yarandığı məkan məhz İnternetdir. $\mathrm{Bu}$ isə həmin folklor nümunələrinin vernakular spesifikaya malik olması, mövzu, məzmun, forma və dil özəlliklərinə sahib olması ilə xarakterizə olunur. Təbii olaraq, İnternet folkloru nümunələrinin də intellektual analizinə, sosial media baş verən proseslərlə əlaqənin aşkarlanmasına, İnternet folkloru faktlarının sosial motivatorlarının müəyyənləşdirilməsinə, aktiv folklor formalarının üzə çıxarılmasına, dövriyyədə olan və ənənəviləşən folklor qəliblərinin öyrənilməsinə, təkrarlanan foklor "tema"larının qeyd olunmasına, müəyyən bir zaman kəsiyində meydana çıxan folklor faktlarının məzmun baxımından təhlil olunmasına, həmin məzmunun sosial proseslərlə korelyativ əlaqələrinin diqqət mərkəzinə gətirilməsinə böyük zərurət vardır.

\section{NӘTIC๐}

Problemlə bağlı mövcud elmi ədəbiyyatların təhlili onu göstərir ki, informasiya təhlükəsizliyi kontekstində folklorun rolu, eyni zamanda folklorun özünün informasiya təhlükəsizliyi məsələsi kifayət qədər aktual və az araşdırılmış sahədir. İnternetin sürətlə genişlənməsi, insanların gündəlik həyat rejimində yeri və rolunun artması, ən müxtəlif ehtiyac və istəklər baxımından şəxslərin ondan asılılığın güclənməsi, bütövlükdə, informasiya təhlükəsizliyinin aktuallaşmasına kibercinayətkarlığın, kiberzorakılığın, gizli sosial şəbəkə və proseslərin üzə çıxarılmasına gətirib çıxarmışdır. Müəyyənləşdirilmişdir ki, bu kontekstə folklor unikal imkanlara malikdir. Qeyd olunmuşdur ki, informasiya təhlükəsizliyinin predmeti kimi, milli folklor resurslarının etibarlı saxlanması, bütövlüyünün və tamlığının qorunması, həmin resursların əlyetərliliyinin təmin olunması müasir dövrün aktual çağırışlarındandır.

\section{ӘDӘBIYYYAT}

[1] Abello, James - Broadwell, Peter - Tangherlini, Timothy R. 2012 Computational Folkloristics. Communications of the ACM 55(7):60-70.

[2] Alıquliyev Ramiz, Niftəliyeva Günay. 2016. "E-dövlətin analizi texnologiyaları: text mining və sosial şəbəkələr". Ekspress informasiya. "İnformasiya texnologiyaları" seriyası. Bak1, "İnformasiya Texnologiyaları" nəşriyyatı, $78 \mathrm{~s}$ h. 


\section{“Informasiya tohlükosizliyinin aktual multidissiplinar elmi-praktiki problemlori” \\ IV respublika konfransl, 14 dekabr 2018-ci il}

[3] Berry Michael W. and Kogan J. 2010. Text mining : applications and theory. Wiley A John Wiley and Sons, Ltd., Publication, 207 p.

[4] Emese Ilyefalvi. 2017 Textualization Strategies, Typological Attempts, 37 Digital Databases: What is the Future of the Comparative Charm Scholarchip? Incantatio An International Journal on Charms, Charmers and Charming Issue 6, Tartu, p. 37-78

[5] Emese Ilyefalvi. 2018. The Theoretical, Methodological and Technical Issues of Digital Folklore Databases and Computational Folkloristics. Acta Ethnographica Hungarica 63(1), 209-258, p. 218

[6] Oliquliyev R.M., İmamverdiyev Y.N. E-Dövlətin informasiya təhlükəsizliyi: aktual tədqiqat istiqamətləri. İnformasiya cəmiyyəti problemləri, №1, 2010.

[7] İmamverdiyev Y.N. E-Dövlətin informasiya təhlükəsizliyinin idarə edilməsinin konseptual modeli. Informasiya comiyyəti problemləri, №1(7), 2013, s. 20-31

[8] Информационная безопасность систем организационного управления. Теоретические основы: в 2 т. / Н.А. Кузнецов, В.В.Кулъба, Е.А.Микрин и др., М., Наука, 2006

[9] McNeill, Lynne S. "The internet is weird". Folkloristics in the digital age. Folklore Fellows’ Network. № 47, December 2015, p. 12-13, 16 17 , p. 16

[10] Мешкова Т.А. Социально-политические аспекты глобальной информатизации // Полис. М., 2002. № 6, с. 24-33

[11] Tangherlini, Timothy R. 2016. Big Folklore: A Special Issue on Computational Folkloristics. The Journal of American Folklore, Vol. 129, No. 511 (Winter), pp. 5-13

[12] Tangherlini, Timothy R. 2013. The Folklore Macroscope: Challenges for a Computational Folkloristics. Western Folklore 72(1): 7-27.

\section{FOLKLORE IS IN INFORMATION SECURITY AND INFORMATION SECURITY IN FOLKLORE}

Hikmat Guliyev

ANAS Institute of Folklore quilyevh@mail.ru

Abstract - The article examines the role of folklore in the context of information security and at the same time the problems about the information security of folklore. The rapid expansion of the Internet, increasing role and place of people in daily life, becoming stronger dependence on people from the point of view of different needs and desires has led to the actualization of information security cybercrime, cyberbullying, the secret social networking and processes. It has been determined that folklore has unique opportunities in this context. It was also noted that, as the subject of information security, the reliable preservation, integrity of national folklore resources, ensuring the equity of these resources are the actual challenges of the modern era. At the same time, classifying the digital folklore resources according to the various parameters and the perspectives about the realization of their intellectual analysis in the Internet were also explained

Keywords - information security, folklore, digital folklore, protection of folklore, Internet folklore, computational folkloristics, cybercrime, national identification 